
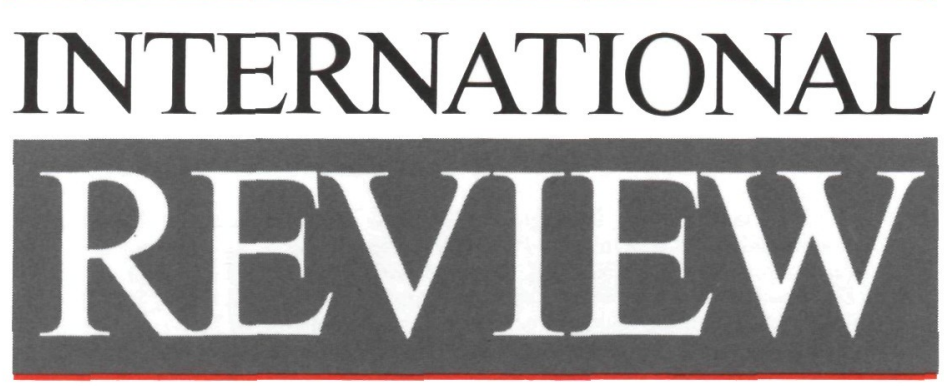

\title{
OF THE RED CROSS
}

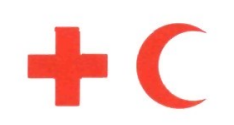

Published every two months by the International Committee of the Red Cross for the International Red Cross and Red Crescent Movement 


\title{
INTERNATIONAL COMMITTEE OF THE RED CROSS
}

Mr. CORNELIO SOMMARUGA, Doctor of Laws of the University of Zurich, Doctor h.c. rer. pol. of Fribourg University (Switzerland), Doctor h.c. in International Relations of Minho University, Braga (Portugal), Doctor h.c. of Medicine of Bologna University (Italy), Doctor h.c. of NiceSophia Antipolis University, Doctor h.c. of Seoul National University (Republic of Korea), President (member since 1986)

Mr. PIERRE KELLER, Doctor of Philosophy in International Relations (Yale), banker, VicePresident (1984)

Mr. ERIC ROETHLISBERGER, Doctorate of Political Science from the Graduate Institute of International Studies in Geneva, Vice-President (1995)

Mr. ULRICH GAUDENZ MIDDENDORP, Doctor of Medicine, lecturer at the Faculty of Medicine of Zurich University, former head of the surgical department of the Cantonal Hospital, Winterthur (1973)

Mrs. RENÉE GUISAN, General Secretary of the international Institut de la Vie, head of medico-social institutions in the Canton of Vaud, member of the International Association for Volunteer Effort (1986)

Mrs. ANNE PETITPIERRE, Doctor of Laws, Barrister, Professor at the Law Faculty of the University of Geneva (1987)

Mr. PAOLO BERNASCONI, Barrister, LL. L., lecturer in economic criminal law at the Universities of St. Gallen and Zurich, former Public Prosecutor at Lugano, member of the Swiss Pro Juventute Foundation (1987)

Mrs. LISELOTTE KRAUS-GURNY, Doctor of Laws of the University of Zurich (1988)

Mrs. SUSY BRUSCHWEILER, nurse, former Director of the Swiss Red Cross College of Nursing in Aarau, Chairwoman, SV-Service, Contract Catering (1988)

Mr. JACQUES FORSTER, Doctor of Economics, Professor at the Graduate Institute of Development Studies in Geneva (1988)

Mr. JACQUES MOREILLON, Bachelor of Laws, Doctor of Political Science, Secretary General of the World Organization of the Scout Movement, former Director General at the ICRC (1988)

Mr. MAX DAETWYLER, graduate in Economics and Social Sciences of the University of Geneva, Scholar in Residence of the International Management Institute (IMI) of Geneva (1989)

Mr. RODOLPHE DE HALLER, M. D., lecturer at the Faculty of Medicine of the University of Geneva, President of the Swiss Association Against Tuberculosis and Lung Diseases (1991)

Mr. DANIEL THURER, LL. D., LL. M. (Cambridge), Professor at the University of Zurich (1991)

Mrs. FRANCESCA POMETTA, Bachelor of Arts, former Swiss Ambassador (1991)

Mr. JEAN-FRANÇOIS AUBERT, LL. D., Professor at the University of Neuchâtel, former member of the Swiss National Council and Council of States (1993)

Mr. JOSEF FELDMANN, Ph.D., tenured professor at the University of St. Gallen, Corps Commander (Rtd.) of the Swiss army (1993)

Mrs. LILIAN UCHTENHAGEN, Doctor of Economics of the University of Basel, former member of the Swiss National Council (1993)

Mr. GEORGES-ANDRÉ CUENDET, Bachelor of Laws of the University of Geneva, graduate of the Institute of Political Studies of the University of Paris, M.A. from Stanford University (USA), member of the Administrative Council of Cologny, Geneva (1993)

Mr. ERNST A. BRUGGER, Doctor in economic geography, general manager of FUNDES, private foundation for sustainable development, consultant for economic development issues, professor at Zurich University (1995)

\section{EXECUTIVE BOARD}

\author{
Mr. CORNELIO SOMMARUGA, President
}

Mr. ERIC ROETHLISBERGER, permanent Vice-President

Mr. JACQUES FORSTER, member of the ICRC

Mrs. ANNE PETITPIERRE, member of the ICRC

Mr. JEAN DE COURTEN, Director of Operations

Mr. PETER FUCHS, Director General

Mr. YVES SANDOZ, Director for Principles, Law

and Relations with the Movement 


\section{INTERNATIONAL REVIEW OF THE RED CROSS}

\section{CONTENTS}

SEPTEMBER-OCTOBER 1995

No. 308

\section{INTERNATIONAL CONFERENCES AND THE MOVEMENT}

François Bugnion: Red Cross law

Philippe Abplanalp: The International Conferences of the Red Cross as a factor for the development of international humanitarian law and the cohesion of the International Red Cross and Red Crescent Movement

\section{WATER AND ARMED CONFLICTS}

Ameur Zemmali: The protection of water in times of armed conflict

\section{INTERNATIONAL COMMITTEE OF THE RED CROSS}

Top ICRC officials re-elected 


\section{MISCELLANEOUS}

Fiftieth Session of the General Assembly of the United Nations Special commemorative meeting of the General Assembly on the occasion of the fiftieth anniversary of the United Nations - Statement by Mr. Cornelio Sommaruga, President of the International Committee of the Red Cross (New York, 22 October 1995)

Accession to Protocol II by the Republic of Colombia ......................... 575

The Republic of Panama ratifies the Protocols ..................................... 575

Accession of the Federated States of Micronesia to the Geneva Conventions and their Additional Protocols .................................... 576

\section{BOOKS AND REVIEWS}

Child Soldiers, the Role of Children in Armed Conflicts (Guy Goodwin-

Gill and Ilene Cohn)

Focus on humanity - A century of photography - Archives of the ICRC

(Nicolas Bouvier, Michèle Mercier and François Bugnion) 